patient leaflet might become confused when reading an "imported" leaflet and at least temporarily lose much of the benefit to which he or she is accustomed. The Allen and Hanburys UK instructions for Ventolin and Becotide are virtually identical and are in the process of being endorsed by the Asthma Society and Friends of the Asthma Research Council for introduction progressively across the range of aerosol preparations.

Finally, the instructions quoted for UK Becotide are from a superseded leaflet and the current instructions are consistent with those quoted by Drs Pozniak and Johnson from the "Italian Becotide leaflet." These quotations are in fact from a leaflet intended for the Middle and Far East and it would appear that the instruction leaflet has been placed into an Italian aerosol package by an agent outside the Glaxo group and hence beyond our control. This of course emphasises my third point.

Examples such as these serve to emphasise some of the important drawbacks associated with the parallel importing of ethical products.

ROGER KEMP

Allen and Hanburys Ltd,
Greenford, Mddx UB6 OHB

Medical Director

\section{Perianal abscess: "Have I excluded} leukaemia?"

SIR,-Dr David N Slater's Lesson of the Week on leukaemia presenting with perianal abscess (15 December, p 1682) concluded that all patients presenting with a perianal abscess should have a full blood count and differential white cell count performed preoperatively to exclude leukaemia.

Although perianal abscess is clearly a common surgical emergency, it is an uncommon presenting feature of leukaemia. In a health service which at present does not run mass screening programmes for the commoner causes of death from cancer it is unjustified to recommend. these investigations routinely for all patients as a preoperative screen for leukaemia. This takes into account the expense of performing many of the investigations out of normal laboratory hours and the fact that the yield for leukaemia is likely to be very low. The conclusion reached from these two interesting but uncommon cases is invalid when the subject is taken in a broader context.

Charles W Pattison

Department of Surgery, East Birmingham Hos

\section{Mental Health Act}

SIR,-Recent correspondence concerning the Mental Health Act 1983 (1 December, p 1542 ; 15 December, p 1694) has not yet highlighted a problem which troubled many psychiatrists working under the old (1959) Act and which unfortunately has not been resolved under the 1983 Act. Urgent discussion of this issue may be required, since the new body set up by the Act, the Mental. Health Act Commission, may rule that a practice followed under the old Act and, of necessity, under the new Act should be regarded as illegal. The problem can be illustrated by the following case.
This man was diagnosed in 1971 as suffering from paranoid schizophrenia. Experience has shown that while he takes injectible psychotropic drugs he remains almost symptom free; when he does not he relapses into an acutely disturbed state, believing that neighbours and workmates are plotting against him, that his house is bugged, and that messages are being conveyed to him by newsreaders on television. At such times he has carried a knife and has terrorised his family, to whom on occasion he has been physically violent. Three times in the past 13 years medication has for one reason or another been stopped and he has relapsed soon afterwards. He has never relapsed while taking medication.

He has never himself accepted the need for regular medication, though it has been possible to maintain him well on low doses-for example, fluphenazine $12.5 \mathrm{mg}$ fortnightly.

In these circumstances and to ensure that he continued to take medication he was detained during most of the 1970 s and early 1980 s under section 26 of the Mental Health Act 1959, though almost all the time he was out of hospital on leave, working, and living with his family. He was seen regularly at the clinic by medical and nursing staff but, in addition, had to be recalled from leave to stay overnight in hospital once every six months, so that the detention order should not lapse. This procedure seemed to the responsible medical officer to be undesirable (since it used a provision of the Act in a way for which it was not intended) but unavoidable if relapse and danger were to be prevented.

Unfortunately no better procedure is available under the new Act. Indeed, it appears that the commission may issue guidelines to say that this practice is improper.

Inquiry among our colleagues suggests that it is common for a consultant psychiatrist to be looking after one or two patients who present this type of problam. However, the importance of the issue goes beyond the small numbers affected. On the one hand, if untreated, such patients represent some of the most dangerous of the mentally ill, who, should they act on their delusions, may require a place in a special hospital. On the other, if treatment in the community cannot be enforced then the alternative must be to keep these patients resident in hospital indefinitely. This is contrary to good patient care, national policies for the mentally ill, and common sense.

We understand that when the present Act was being framed the possibility of including a community treatment order was considered. Is it not time for such a proposal to be revived and enacted?

\section{JULIAN CANDY}

St John's Hospital

ErIC Crouch Aylesbury, Bucks

SIR,-The anonymous GP is attacking the wrong target in his letter (1 December, p 1542) about the Mental Health Act 1983. The Act itself does nothing to put patients' lives at risk if it is interpreted properly; the problem, if there is one, lies with those who use it.

The section authorising admission for assessment in the case of emergency was invoked under the 1959 Mental Health Act far more often than was envisaged by the Royal Commission on whose recommendations the Act was based. ${ }^{2}$ Some commentators suggested that this did not necessarily mean abuse, ${ }^{3}$ but the large regional variation in its use did indicate that the procedure was used inappropriately on a number of occasions. For this reason the 1983 Act made some modest changes in the time limits within which the section can be used.
The faults reported in the GP's letter do indicate that the senior social worker was wrong not to send out an approved social worker to make an assessment when the GP requested it. The social worker is the person who makes an application for admission and in this case it is unclear how he or she could decide which section, if any, was appropriate without seeing the potential patient. On the other hand, the inability of the doctor to get a speedy response to his request for a domiciliary visit and, therefore, if warranted, a second medical recommendation as required for a section 2 admission is an example of a more widespread problem. Any person who is going to be deprived of his or her liberty, even when there is good reason, is entitled to a full and competent assessment, and the Act, save in emergencies, defines this as meaning the involvement of two doctors. Social workers are correctly trained to understand that one of their roles is to ensure that this happens and one of the hindrances they have to cope with is the unwillingness in many areas of health authorities and hospital doctors to develop procedures to enable this good practice to occur.

Obviously the social worker's failure to bring the correct forms was inefficient. Before GPs cast too many stones, however, they should perhaps consider putting their own house in order. Unlike social workers most GPs have received no training in the Mental Health Act despite the fact that they often play a crucial part in its implementation.

Many of the problems of the type referred to in the GP's letter could be circumvented if all those concerned in implementing the legislation actually talked to each other more and developed codes of practice that offered the opportunity to resolve the conflicts that necessarily arise from the different professional ideologies of those concerned in implementing the Act-and which are one of the major safeguards offered for the protection of the patient.

William Bingley Legal Director

MIND (National Association for Mental Health),
London W1N 2ED

1 Royal Commission on the Law relating to Mental Illiness and Mental Deficiency. Report. London: HMSO, 1957. (Cmnd 169.) 2 Department of Health and Social Services. A review

1976.
Bean . Compulsory admission to mental hospitals

Chichester: John Wiley and Sons, 1980:69.

\section{William Withering and digitalis}

SIR,-Unless my memory is at fault there is an account in Tacitus of a king of Parthia at death's door with bodily swelling and shortness of breath. His son, covetous of the throne, determined to expedite his father's demise. He had him poisoned with foxglove. To his intense chagrin the father recovered from his illness and, while not in rude health, showed every sign of living on.

Public rejoicing was brief. The son had him strangled.

This must be the first account of (involuntary) digitalis therapy. Finally, I can only lament that Withering (5 January, $p$ 7) did not publish his findings 12 months earlier. Digatilis might have given Dr Johnson a few more years of life (he died in December 1784).

D A MOORE

Occupational Health and Safety Services, Scottish and Newcastle Breweries, 